\title{
IPO Underpricing in the Hospitality Industry: A Necessary Evil?
}

\author{
Linda Canina \\ Charles Chang \\ Scott Gibson
}

\begin{abstract}
Hospitality initial public offerings (IPOs) experienced average first-day price increases of $17.1 \%$ between January 1981 and December 2001. This price increase, referred to as IPO underpricing, represents a substantial opportunity cost to the owners of the issuing firm. IPO underpricing is a critical consideration for managers of private hospitality firms who are considering going public. The increased liquidity, easier access to equity capital, and other benefits that accrue to publicly traded firms must be carefully weighed against the significant cost of underpricing. This paper explains the relationship between the marketing process of IPOs and the degree of underpricing. We test the hypothesis that underpricing is a reward for the information revealed by regular investors during the marketing process of the IPO. We explain why underpricing is a necessity for managers of private hospitality firms if they choose to go public. For managers of private hospitality firms who are considering taking their firms public, our results provide an historical benchmark for the underpricing that they can expect to transfer to outside investors which is different from that of the overall market. Beyond benchmarking the cost of going public, we test theories that predict underpricing and investigate the use of share allocations as an incentive for truth telling.
\end{abstract}

JEL: G24, G32

Keywords: IPO underpricing, Information Asymmetry 


\section{Introduction}

Issuing publicly traded stock for the first time is a highpoint for any company. The manager/owner's motivations for moving forward with an initial public offering (IPO) are varied, but, as with most decisions, the manager/owner of a private firm must carefully weigh the benefits of an IPO against its costs. Potential benefits include the ability to raise capital in the public markets on more attractive terms than in private circles, increased liquidity for managers and other insiders, and increased recognition and credibility with other stakeholders. These benefits, however, come at considerable direct and indirect costs. For U.S. firms, Lee, Lockhead, and Ritter (1996) find that the direct costs, such as investment-banking commissions, average about $11.0 \%$ of IPO proceeds. Less obvious, but often more costly, is an additional indirect cost commonly referred to as IPO underpricing.

IPO underpricing is defined as the IPO's first day return. It represents the potential lost proceeds generated by the difference in the offer price at which shares are initially sold to the public and the closing price after the first day of trading. Historically, IPOs have shown economically significant first-day price increases. A study of all U.S. IPOs over 1980 to 2000 by Loughran and Ritter (2002), for example, documents an average first-day return of 18.9 percent. Zheng and Strangeland (2007) find an average first-day return of 12.91 percent over the period 1982-1998. Krigman, et al (1999) further show that these returns are not given back in the first year of the IPO. They estimated an average first day return of 12.3 percent over the $1988-1995$ period. Ritter and Welch (2002) confirm the result that there is a significantly positive return over a three-year holding period following the IPO . In sum, for the overall market, there is 
widespread evidence of significantly positive first-day returns and prices increase and stay high following the IPO.

Since early work by Stoll and Curley (1970), Logue (1973) and Ibbotson (1975), the empirical regularity of significant first-day IPO returns have typically been referred to as "IPO underpricing" because of the wealth consequences for private owners who decide to go public, selling part or all of their firms to outside investors. To illustrate, consider an IPO with, say, an offer price of $\$ 10.00$ and a first-day closing price of $\$ 11.89$. The $\$ 1.89$ underpricing represents a one-day return of 18.9 percent for investors who bought shares at the offer price. From the original owner's viewpoint, however, company shares were sold for less than they were worth. Although the capital markets value the shares at $\$ 11.89$, the original owners only receive the $\$ 10.00$ offer price (less, of course, fees paid to the underwriter). This transaction with typical underpricing raises an interesting question: Why do private owners give away such a large proportion of their firms' value to outside investors in the process of going public?

Benveniste and Spindt (1989) provide an answer. In their well-known theoretical model of the firm-commitment IPO process typically used in the United States, underpricing is critical to overcoming information asymmetries between private firm managers/owners and potential investors in the public capital markets. More specifically, their model shows that underpricing is an economic necessity as it entices "smart money" investors to truthfully participate in the price-setting process.

Although Strangeland and Zheng (2007) find that IPO underpricing may be affected by industry-specific characteristics, there is a small amount of work related to IPOs in the hospitality industry. Gu (1996) studies IPOs in the gaming sector and finds 
that they under-perform in the long run. His study, however, does not explicitly model and investigate underpricing. Atkinson and LeBruto (1995) also focus their attention on the gaming industry and find a substantial underpricing of $30.63 \%$, though they do not posit reasons for why and do not model the price-setting process. However, these results provide evidence that differences exist between the degree of underpricing for the overall market and for specific industries. As a result, it is informative to estimate the degree of undepricing in the hospitality industry and to test the theoretical model of Benveniste and Spindt (1989). Canina (1996) and Canina and Gibson (2003) study the entire hospitality industry. Together, they document underpricing in IPOs and show that the long-run performance of hospitality IPOs are higher than that of the average company in the overall market. However, they do not formally model the underpricing phenomenon or the price-setting process and do not investigate the share allocation decision, which are the focuses of this study. We contribute to this literature by providing evidence that underpricing is purposeful, is a necessary component of the IPO process, is incentivized through manipulation of share allocation, and is not explained by prevailing market conditions. As will be discussed in detail later, our results are consistent with investment banks offering a positive first-day return to investors to induce them to reveal their true demand for the stock. In addition, we document the differences in underpricing between the overall market and the hospitality sector. The difference is substantial and is consistent with our general explanation that underpricing is driven by truthful information disclosure during the bookbuilding process.

In this paper, we test the theoretical predictions of Benveniste and Spindt (1989) and others on a sample comprising 123 firm-commitment hospitality IPOs filed between 
January 1981 and December 2001. Our efforts, the first ever to test the empirical implications of these models in the hospitality industry, serve a twofold purpose. First, as soon will become clear in further discussion of the economic rationale for IPO underpricing, predictions emerge about the pattern of underpricing across IPOs. These predictions are derived from the theoretical models of Benveniste and Spindt (1989), Benveniste and Wilhelm (1990) and Spatt and Srivastava (1991). We design tests of these predictions and find that underpricing theories prove consistent with what we observe in the hospitality industry. The overall results for the hospitality sector are similar to results of other industries presented in aggregate by Hanley (1993). However, the magnitude of our estimates differ from those in the overall market. Therefore, since the degree of underpicing is different in the hospitality industry as well as for its constituent sectors hotels and restaurants, our results also provide an historical benchmark for underpricing in the overall hospitality industry as well as for hotels and restaurants individually. Our results thus enable lodging and restaurant manager/owners of private hospitality firms to more accurately benchmark the cost of going public.

The remainder of the article is organized as follows. In Section 1, we review the theoretical rationale for IPO underpricing and derive testable implications. We describe our data and sample composition in Section 2. In Section 3, we describe our empirical methodology; results are also presented and interpreted. Concluding remarks are made in Section 4.

\section{Economic Rationale for Underpricing}

In order to understand the economic rationale for IPO underpricing, first note the 
important role of the investment bank as the underwriter of the IPO. This is accomplished through a brief review of a landmark study by Akerlof (1970). Akerlof (1970) shows that markets do not work well when asymmetrically informed buyers and sellers try to make one-time transactions without the intervention of an intermediary. If buyers cannot verify the quality of a product, they should always believe that a product is worth less than the price offered by the seller. The intuition is quite simple: if the product were worth more than the sale price, why would the seller be willing to part with it? Given that it is a one-time transaction, the seller does not care about damaging his reputation and so has nothing to lose. In this case, buyers who accept the seller's price will always over-pay, thereby inducing buyers to leave the market and, in the worst case, for trading to cease. One plausible remedy is the introduction of a reputable intermediary whose job it is to certify value. The intermediary whose business it is to make repeated transactions has her reputation on the line. As long as the intermediary evaluates products honestly, her reputation is protected and her business can continue successfully.

The relevance of Akerlof's argument in the IPO market can be illustrated with an example. Consider the market for IPOs in which two equally likely types of IPO issues exist: those of good companies worth $\$ 20$ per share and those of bad companies worth $\$ 10$ per share. Potential IPO issuers know the value of their company. Potential investors, however, can not discern whether the company is good or bad. Given that half of the issues being offered are from good companies worth $\$ 20$ per share and half are from bad companies worth $\$ 10$ per share, investors ought to be willing to pay the average of $\$ 15$ per share. However, the potential issuers of good companies are unwilling to offer their shares for $\$ 15$. Potential investors understand this reluctance to offer shares of good 
companies, and thus are only willing to pay $\$ 10$ per share since they correctly believe that they are purchasing the shares of a bad company. As a result, the market collapses with only the shares of the bad company being offered.

In the IPO market, when investors buy shares of a company, they are purchasing a portion of the firm's future profits: the higher the present value of their expected future profits, the more the shares are worth. However, buyers are obliged to believe that firms will over-state their profitability in an effort to inflate prices and thus require an impartial third party, the investment bank, to confirm the firms' claims. Potential IPO firms that indeed have positive prospects will seek out and pay for reputable intermediaries who will research the firm and communicate honest evaluations to prospective buyers. Potential IPO firms with shabby prospects cannot approach these intermediaries for fear of being uncovered. In this manner, poor quality IPOs are filtered out and intermediaries take on the role of information accumulators.

Investment banks in their role as an underwriting of the IPO serve as a reputable intermediary during the underwriting process. This process consists of two parts. The purpose of the first part is to provide credible information to the investors useful for evaluating the value and riskiness of the firm. This involves the development of the "prospectus" by auditors and analysts from the investment bank in conjunction with the management of the issuing firm. The prospectus, which is delivered to outside investors, comprehensively describes the issuing firm's business, including its future plans, financial history, and potential risks. Investors have faith that the information contained in the prospectus is accurate because the investment bank has its reputation on the line. Banks have the incentive to report this information honestly in order to maintain its 
professional reputation and ensure future business. The investment bank is in the business of underwriting IPOs. If the investment bank misrepresents a firm's prospects in the prospectus, its future underwriting business suffers.

The bank is responsible for setting a price at which cynicism in the market is offset by verifiable expectations of future performance for the firm. The offer price set by the underwriter must simultaneously compensate investors for accepting the risk inherent in being on the losing end of information asymmetry and raise the maximum amount of capital for the IPO firm. This rationale is the basis of the theoretical models developed by Benveniste and Spindt (1989), Benveniste and Wilhelm (1990) and, Spatt and Srivastava (1991), and it suggests that it is this balancing act that is the impetus to IPO underpricing.

In order to raise the desired amount of capital for the issuing firm investors must be willing to reveal their true valuation during the second part of the underwriting process referred to as the bookbuilding process. Investors would like to pay the lowest price possible but in order to maintain their reputation as a credible underwriter the investment bank must raise the maximum amount of capital for the IPO issuing firm. Investors have accurate information on which to base their valuation through the prospectus, but they do not have the incentive to disclose voluntarily what they think the shares are worth. Investors have the incentive to keep their valuation private and attempt to lowball their offers in the hope of keeping the offer price low.

The bookbuilding process occurs during the "road show", and it is designed to get the most that it can for the firm that is represents in the going-public process. During the "road show" the underwriter communicates its findings to the public and attempts to 
extract from the public what it is willing to pay for the IPO issue. The investment bank's objective is to get investors to reveal truthfully their private valuations and to set the IPO offer price according to those valuations.

The theoretical work of Benveniste and Spindt (1989), Benveniste and Wilhelm (1990) and Spatt and Srivastava (1991) posits that underpricing serves to motivate investors to reveal truthful indications of interest. The simple intuition is that by allowing investors to receive a positive return by setting the offer price below the true price, one can induce investors to participate in the bookbuilding process. The bookbuilding process is designed for just that. Specifically, prior to bookbuilding, the underwriting bank sets a range of possible offer prices called a "filing range," say $\$ 11$ to $\$ 13$ a share. Ostensibly, this $\$ 11$ to $\$ 13$ range represents the investment bank's best estimate of what the final offer price will be but is in no way binding. The investment bank and issuing firm then conduct a "road show" where the firm is presented to major investors, sometimes called regular investors or a selling group. Investors may then indicate how many shares they would like to buy at a price of $\$ 9, \$ 11, \$ 13, \$ 15$, and so on. These non-binding bids are collected in a "book," hence the term "bookbuilding." Upon completion of the road show, the investment bank analyzes the book and sets the offer price and allocation of shares. If the investment bank is successful in acquiring truthful indications of interest, that is, a reliable representation of aggregate demand, it will be able to estimate with a high degree of accuracy the price at which shares will sell once they begin to trade in the public capital markets.

Benveniste and Spindt (1989) model this process and show that the following set of rules will induce investors to reveal their demand truthfully: 
1. Indications of interest are not binding hence investors are not forced to purchase in the case that the IPO fails. Moreover, they will not feel "trapped" in case future information renders their original bids too aggressive.

2. All investors get their shares at an identical offer price. This helps to ensure that investors are not discouraged from offering a high price.

3. Investors that make stronger indications of interest receive a greater allocation of shares. Investors who bid high are offered more shares to provide incentive for them not to low-ball. Thus, if one feels an IPO will be strong, they will bid a high price. They are insured the same price as everyone else (rule 2) but will receive more shares as a reward.

4. The offer price is related to the strength and breadth of interest: the stronger the overall indications of interest, the higher the offer price. In other words, the offer price reflects the information revealed in bookbuilding.

5. The investment bank maintains a direct link between anticipated underpricing (i.e., the anticipated first-day return) and the overall strength of the book: the stronger the overall indications of interest, the greater the underpricing. If interest is high and the offer price is set high (rule 4), the investment bank must ensure that all investors will receive a fair return once the firm goes IPO. Otherwise, the next time the bank approaches investors, they will be unwilling to truthfully reveal their interest, knowing that in doing so, offer price will rise and their return will fall. Only in ensuring that the first-day return is proportional to the offer price can investment banks prove to investors that they will be not be punished for revealing their information. 
These rules are critical to building a book containing truthful indications of interest by which the investment bank determines the offer price and allocation of shares. Only if all five of these criteria are met, will investors reveal their true valuations of all deals, regardless of the quality of the deal itself. Recent work by Bubna and Prabhala (2007) investigates a large number of IPO books directly and finds that this process indeed serves to uncover truthful signals of interest and hence price. Lin et al (2003) further find that bookbuilding simultaneously rewards investors for truth-telling while also reducing total underpricing, in essence benefiting both investors and issuing firms.

In order to get a better idea of how these rules induce an investor to reveal a truthful indication of interest, consider how an investor would respond to the set of rules when asked by the investment bank for his indication of interest. Suppose that all the regular investors like the deal. If they all truthfully submit a strong indication of interest, then the investment bank will increase the offer price (rule 4) and allocate each the appropriate number of shares based upon the relative strength of their indication of interest (rule 3). Since all the regular investors submitted truthful indications of interest in this scenario then the investment bank has a good estimate of the price at which the shares will sell once they begin trading. The investment bank simply sets the offer price below this estimated market value to underprice the issue (rule 5). Each investor profits by telling the truth because they are allocated shares at the same offer price (rule 2) that has intentionally been set below the expected market price.

Suppose that an investor deviates from the other investors and lies by submitting a weak indication of interest. The weak indication of interest will result in a weaker book and a lower offer price (rule 4) but this investor will not be allocated shares (rule 3). So 
this investor is shut out of the deal rather than profiting by telling the truth.

Let us now examine the situation in which all the investors dislike the deal and truthfully submit weak indications of interest. The investment bank once again knows the market price at which the shares will sell once they begin trading. Clearly the weak book points to a market price at the lower part of the initial offer range or perhaps, for very weak books, below the range. With a weak book, the investment banker does not underprice the issue and sets the offer price close to this market price. Each of the regular investors will be asked to buy a number of shares at this offer price. Moreover, the investors may be asked to hold a portion of their shares for a period after the issue. Honoring the request will not, on average, generate excess losses since shares are bought at a fair market price, but it will not generate excess profits either. Why not deny the request to buy and hold shares? The repeated nature of the IPO game once again plays a critical role. As pointed out by Sherman (2000), if a regular investor refuses to buy and hold shares in a weak IPO, the investment banker can rescind her membership in the "club" of regular investors. Of course, a loss of club membership would be costly going forward, as the investor's ability to profit from her information would be severely impaired.

Now suppose that an investor instead deviates from the other investors and lies by submitting a strong indication of interest. In that case, she may be rewarded by a request to buy and hold even more shares in the weak IPO. As for deals an investor likes, she is best served by telling the truth for deals she dislikes.

The bookbuilding process is thus what a financial economist calls a "truth-telling mechanism." To tell the truth about what they think of the deal is in investors' best 
interest. Recognize that underpricing the issue when the overall book is strong is critical to truth telling. To see this, consider an investor's incentive in the scenario posed above if instead of underpricing the issue when the book is strong, the investment bank sets an offer price exactly equal to the market price predicted by the book. Without underpricing, if an investor tells the truth by indicating that she likes the deal, she is allocated shares but pays exactly what they are worth. So, by telling the truth, she does not profit. She is better off lying in the hope of driving down the offer price and picking up shares at depressed prices in the market once they begin to trade. Without underpricing, regular investors have no reason to participate in the bookbuilding process.

The important stipulation is that, in order to induce truth-telling, banks must under-price strong IPOs and not weak ones, thereby generating incentives to indicating strength only in the case of a strong demand. Evidence presented by Smith and Kutsuna (2000) indeed find that participants in bookbuilding are better off than those who are not and that bookbuilding ultimately enhances value for both large and small issuers.

The empirical implication of Benveniste and Spindt's (1989) model is that changes in the offer price between the filing of the prospectus and the offer date are a result of information gathered by underwriters from investors during the bookbuilding period. Recall from our earlier discussion that the offer price and allocation chosen by the investment bank is related to the strength and breadth of interest demonstrated during the bookbuilding effort. The stronger are the overall indications of interest, the higher is the offer price and the higher is the allocation. The strength of the book will thus manifest itself in how the offer price is set relative to the filing range. A strong book is evidenced by an offer price that is set above the filing range. Similarly, a weak book is 
evidenced by an offer price that is set below the filing range. Also recall that the investment bank provides regular investors with an incentive to reveal truthfully their demand for an issue by maintaining a direct link between both anticipated underpricing and allocation and the overall strength of the book. The stronger is the book, the greater is the underpricing and the greater is the allocation.

Putting all of the above together, we have the following testable empirical implications:

1. A strong (weak) book should generate an offer price that is set high (low) and should be coupled with a large (small) underpricing.

2. A strong (weak) bid in the bookbuilding process should accompany a large (small) allocation of shares.

In other words, underpricing should be greatest when the offer price is set above the filing range and lowest when the offer price is set below the filing range; and the percentage change in the number of shares offered relative to the number of shares filed in the preliminary prospectus should be greatest when the offer price is set above the filing range and lowest when the offer price is set below the filing range. These are the two empirical implications of the theoretical models first developed by Benveniste and Spindt (1989) that are tested in this study.

\section{Data and Sample Construction}

Our dataset of hospitality IPOs draws from two sources: the Securities Data Corporation (SDC) and the Center for Research in Securities Prices (CRSP). The total sample consists of 123 firm-commitment hospitality IPOs filed between January 1981 and December 2001. SDC reports company and offering characteristics including the 
underwriter, the initial offer price filing range reported in the prospectus, the number of shares filed in the prospectus, the final offer price, and the number of shares offered. The sample does not include IPOs with an offer price less than $\$ 5.00$. Issues that have missing values for the high offer price, the low offer price, the number of shares filed, or the number of shares offered are excluded from the data sample. The CRSP database provides the closing price on the first trading day for each IPO necessary to calculate the first-day return and, hence, underpricing.

We separate our hospitality sample of IPOs into restaurant and hotel sub-groups using each firm's Standard Industrial Classification (SIC) Code. The SIC "Restaurant" classification is narrow in scope, whereas the SIC "Hotel" classification is more broadly defined to include hotel management/ownership firms, gaming firms, and cruise lines. Our sample includes 91 restaurant firms and 32 hotel firms. Table 1 reports the number of IPOs, and the average value of IPOs in thousands of dollars by year and over various periods for the hospitality sector as a whole and for the restaurant and hotel sectors separately. Except for 1988, 1990, and 2000, at least one hospitality firm went public every year from 1981 through 2001, with particularly active years in the early-to-mid 80's and the mid 90's. Slowdowns in IPOs seem to coincide with weakness in the overall stock market pursuant to market crashes in 1987 and 2000. When examined separately, the Restaurant and Hotel IPO markets appear to share periods of activity and inactivity in terms of both number of IPOs and total value offered. Hotel firms that went public raised, on average, almost three times as much per IPO as restaurant firms, but Hotel IPOs are far less frequent, particularly in the first decade of our dataset. A total of nearly $\$ 4$ billion was raised in 123 IPOs over the course of 21 years. 


\section{Empirical Evidence}

\subsection{Initial Filing Range Accuracy}

Reputational concerns on the part of investment banks imply that the initial filing range reported in the prospectus for the offer price is an unbiased assessment of the eventual offer price at which shares will be offered to regular investors. In other words, filings ranges should not be systematically high or low relative to the final offer price. If it were, investors would quickly learn of this and adjust their bidding appropriately. For example, if an investment bank consistently sets the initial filing range too high, investors will always bid lower than the initial filing range, knowing that the filing range is too high. As such, investment banks wishing to maintain a reputation of honest valuation should seek to set an initial filing range that is unbiased. To test whether investment banks that underwrite hospitality IPOs do indeed set an unbiased filing range on average, we conduct statistical tests used to address the biasness of an estimator. This is accomplished by testing whether or not the mean difference between the mid-point of the filing range and the offer price, referred to as the offer price revision, equals zero. The mid-point of the filing range is used as an estimate of the expected offer price. For every IPO in our sample we compute the difference between the offer price and the mid point of the filing range and then compute the mean of the difference. We then use the tstatistic in order to determine whether the mean difference is statistically different from zero. In addition, we tested the mean percentage difference between the two.

Specifically, let $\mathrm{P}_{\mathrm{O}}$ represent the offer price set at completion of the road show and $\mathrm{P}_{\mathrm{M}}$ represent the mid-point of the filing range $\left(\mathrm{P}_{\mathrm{L}}, \mathrm{P}_{\mathrm{H}}\right)$ reported in the prospectus 
where $\mathrm{P}_{\mathrm{L}}$ and $\mathrm{P}_{\mathrm{H}}$ are the lowest and highest prices in the filing range, respectively. If the filing range is unbiased, then on average the offer price revision, $\mathrm{P}_{\mathrm{O}}-\mathrm{P}_{\mathrm{M}}$ should be insignificantly different from zero. By analogy, $\left(\mathrm{P}_{\mathrm{O}}-\mathrm{P}_{\mathrm{M}}\right) / \mathrm{P}_{\mathrm{M}}$ is the difference between the offer price and the midpoint of the filing range in percentage terms, referred to as the percentage offer price revision. The average value for each of these measures was computed by first computing the value for each IPO and then averaging this value across IPOs. For example, for the mean percentage offer price revision, first the percentage difference was computed for each IPO and then the average was taken of these computed values across the IPOs.

Table 2 shows the values of various variables of interest related to the determination of whether the initial filing offer range reported in the prospectus is an unbiased assessment of the final offer price in which shares are offered to regular investors. The values are reported for the hospitality industry as a whole in Panel A, as well as for two subsamples: restaurants, Panel B, and hotels, Panel C. For each of these three data samples - hospitality, restaurants and hotels, the results are presented across all IPOs in Column (1). In addition, in order to get a sense of the relationship between the final offer price and the filing range, Table 2 also reports the same information for three subsamples of the IPOs categorized based upon the relationship between the final offer price and the filing range. The three categories were defined as: the "Below" group where the final offer price was set below the low of the filing offer range; the "Within" group where the final offer price was set between the low and the high of the offer range; and the "Above" group where the final offer price was set above the high of the offer 
range. For illustrative purposes, consider an IPO with a filing range of $\$ 15$ to $\$ 17$. The three categories represent a final offer price below $\$ 15$, between $\$ 15$ and $\$ 17$, and above \$17. The IPOs included in Column (2) represent those in which the offer price was set below the offer range (henceforth "Below"); Column (3) represent those in which the offer price was set within the offer range (henceforth "Within"); and Column (4) represent those in which the offer price was set above the offer range (henceforth "Above").

The mean offer price revision is insignificantly different from zero as shown in Table 2, Column (1). For the hospitality industry as a whole, the average value is $-\$ 0.11$; for the restaurant sector it is $-\$ 0.16$; and, for the hotel sector is $\$ 0.13$. The low t-statistics indicate that the difference is insignificantly different from zero. Although investment banks' filing range estimates, on average, were slightly high for restaurant firms and slightly low for hotel firms, the lack of statistical significance in the test of the differences suggests that investment banks were not systematically biased in setting the filing range. The empirical evidence is thus consistent with the theory that the initial filing range contained in the prospectus is an unbiased estimate of the final offer price.

The results presented in Table 2 for each of the three hospitality subsamples, the "Below", Within" and "Above" groups, provide further evidence that supports the result that the filing offer range is an unbiased estimate of the final offer price. Investigation of the percentage of IPOs with a final offer price that falls below, within, and above the filing range lends further credence to the results presented above. The variable entitled percentage of IPOs shows that about half of the time investment banks were successful in setting a filing range which encompassed the final offer price. Of the 123 total 
hospitality IPOs, 64 had a final offer price within the initial filing range, which represents $52 \%$ of all deals. In 32 instances or $26 \%$ of all deals the offer price was below the range and 27 times or $22 \%$ it was above. Moreover, the magnitude of the average dollar offer price revisions and average percentage offer price revisions are symmetric when the offer price is below the offer range and for when the offer price is above the offer range. ${ }^{1}$ For the "Below" group the average dollar revision was $-\$ 2.55$ while for the "Above" group this value was $\$ 2.77$. Again, there is no evidence of bias here.

These findings are mirrored in each of the two industries: $49.0 \%$ of the time the offer price was within the range for Restaurants and $59.0 \%$ of the time for Hotels. The percentage of IPOs in the "Above" vs "Below" groups are $22 \%$ vs $29 \%$ and $22 \%$ vs $19 \%$ for Restaurants and Hotels respectively. Again, these findings show that the "Above" and "Below" groups are roughly the same size. In addition, the absolute value of the magnitude of the mean offer price revision are similar for the "Above" and "Below" groups. The results when the hotel and restaurant sectors were analyzed separately provide further evidence that the filing range is unbiased.

Overall, our results suggest that investment banks were unbiased in setting initial filing ranges for the hospitality industry overall and for the hotel and restaurant sectors. Our qualitative conclusion about the biasness of range-setting behavior is similar to that of Jenkinson et al (2003), who study European IPOs. Jenkinson et al (2003) find that European IPOs were rarely priced outside of initial filing ranges, concluding that European investment banks were unbiased when setting the ranges.

\footnotetext{
${ }^{1}$ The conclusions for the dollar offer price revision and the percentage offer price revision are consistent. As a result, only the dollar offer price revision results are discussed henceforth.
} 


\subsection{IPO Underpricing and Demand Revelation}

Now, let us turn our attention to underpricing, where underpricing is defined as the first-day IPO return. If underpricing is an incentive for truthful revelation of information, it should be positive for all IPOs according to rule 5 . However, it should be most significantly so for IPOs with strong demand and for which bookbuilding has generated a high offer price relative to the offer range, rule 5. Let the first-day return be defined as follows where $P_{O}$ is the final offer price and $P_{1}$ is the closing price on the first day of trading:

First day return $=\left(P_{1}-P_{0}\right) / P_{0}$

Table 3 presents findings regarding first-day IPO returns. The average first-day return for the entire Hospitality sector and the Restaurant and Hotel subgroups as shown in Column (1) are consistently positive (about 17\%) and all statistically different from zero (with p-values less than $1 \%$ in each case). ${ }^{2}$ For the hospitality sector as a whole, the underpricing is larger and significantly so when the offer price is above the filing range (strong demand). Indeed, when the offer price was within or above the filing range, the underpricing was positive and significantly so, $14 \%$ and $39 \%$ respectively. When the offer price was below the filing range, the underpricing, $4.64 \%$ is not statistically different from zero. The F-statistic of 19.06 confirms that the means of each category, above, within, or below filing range, are significantly different. An additional test, the ttest (t-statistic of 5.49), shows that the difference between the above- and below-filing range underpricings is likewise large (almost 35\%) and statistically significant. This

\footnotetext{
${ }^{2}$ We test whether underpricing is related to market conditions at the time of the IPO and find that they are not significantly related. In other words, positive first-day returns are not explained by strong market conditions. Detailed results are available upon request.
} 
observed pattern of first-day returns is consistent with the theory that underpricing is the price or the reward paid to regular investors for truthful revelation of demand. That is, IPOs with strong demand (the "Above" group), during bookbuilding, result in high offer prices relative to the offer range, rule 4, and reward investors with the largest first-day return, rule 5. We found that the highest underpricing of $39.41 \%$ occurred when the offer price was set above the offer range, rule 5. The second highest degree of underpricing of $13.92 \%$ occurred for IPOs in which the offer price was set within the filing range (the "Within" group), rule 5. While the group with the weakest demand (the "Below" group), those with essentially no underpricing are found for the group of IPOs in which the offer price is set below the offer range, rule 5. This pattern of underpricing in which the highest level of underpricing occurs for the IPOs in which the offer price was set above the filing range and the lowest level occurs for those below the filing range is consistent with the rules used by the investment bank during the bookbuilding process. ${ }^{3}$

The caveat seems to be the industry-specific investigation of the Hotel industry. For the hotel sample, the differences in initial returns among each of these three categories is weakly significant as determined by the F-statistic, but pair-wise tests do not show that the "Above" underpricing exceeds the "Below". Though the difference is still quite large, almost $25 \%$, this is not statistically significant, due mostly to the small size of the "Below" sample and the resulting lack of statistical power extracted.

In addition, Table 3 reports the percentage of IPOs with first-day returns greater than zero. When an investment bank sets the offer price above the file range, the first-

\footnotetext{
${ }^{3}$ If underpricing tended to be reversed in subsequent periods, the relation between first-day returns and later returns would be negative. However, consistent with the findings of Krigman et al (1999) and Ritter and Welch (2002), we find here that underpricing is persistent as first-day returns are not significantly related to subsequent returns at either the weekly or annual horizon. Detailed results are available upon request.
} 
day return was greater than zero in every instance. This suggests that after building the book, investment banks purposefully set the offer price lower than what they believe the fair market price to be, even after raising the offer price in accordance with revealed demand. If underpricing were not purposeful, one might expect that, from time to time, banks would increase the offer price so much as to result in zero or negative underpricing from time to time. This study finds not a single instance of this in the above-filing-range category. As such, we conclude the significantly positive underpricing of that category is purposeful.

Table 4 shows a comparison of the average underpricing for the overall market, the casino industry and the hospitality industry over various periods. The periods correspond to those of the previous studies. For example, Strangeland and Zheng (2007) analyzed IPOs for the overall market for the 1982-1988 period. In order to provide a valid comparison, we computed the average underpricing for hospitality IPOs over the same period (presented in column 4). It is evident that the degree of underpricing is consistently higher in the hospitality sector than it is in the overall market. Strangeland and Zheng (2007) document an average underpricing of 12.91 percent for the overall market while for the hospitality sector it is 17.47 percent over the 1982-1988 period. Similarly over the 1990-1998 period, Loughran and Ritter provide evidence of an average underpricing of 14.8 percent whereas for the hospitality IPOs it is 22.14 percent over the same time period. The same pattern emerges when the reference group is the casino industry. Atkinson and LeBruto (1995) found that the average underpricing for casino IPOs during the years 1992-1993 was 30.63 percent. The average underpricing for hospitality stocks was 36.77 percent over that same two year period. As a result of the industry specific differences, it is important for hospitality managers to use the historical average for the hospitality industry as 
the benchmark when evaluating the costs associated with going public.

The same pattern emerges when the average underpricing is examined for each of the groups categorized according to the final offer price relative to the filing range. As shown in Table 5, Hanley (1993) found that the average underpricing of IPOs in the overall market with and offer price less than, within, and above the filing range was 0.6 percent, 10.00 percent and 20.70 percent over the $1983-1987$ period. Whereas, for hospitality IPOs the average underpricing was 0.32 percent, 11.89 percent and 30.26 percent respectively over that same period. Once again, we find evidence that the average underpricing for hospitality stocks is higher than that of the overall market.

The explanation for these findings potentially lies in the public and readily identifiable nature of hospitality firms and their operations. Hospitality firms are generally easily-identifiable, publicly visible companies. While the return potential for a Silicon Valley firm producing integrated circuit designs may be quite mysterious for the average investor, many, if not most investors, know of P.F. Chang's (a restaurant company that went public in December 1998). Many have patronized the establishment itself and most will find its business model to be relatively intuitive. In contrast, consider MKS, a semiconductor manufacturing company listed just months after P.F. Chang's. While MKS may have just as promising a future as P.F. Chang's, it is quite likely that the average investor would find it more difficult to evaluate the future prospects of MKS owing to lack of a fundamental knowledge of the semiconductor industry. As a result, the information revealed during the bookbuilding process can be less straightforward and palatable to investors, resulting in smaller first-day price movements (less than $1 \%$ first-day return for MKS versus more than 50\% for P.F. Chang's). Note, however, that MKS has 
performed better than P.F. Chang's since their IPOs so it is not the case that the value of MKS is not eventually revealed. It just is not revealed as thoroughly in the bookbuilding process. ${ }^{4}$

Note also that the majority of firms in our dataset are restaurant firms and that the underpricing of restaurant firms is higher than that of hotels, perhaps for the same reason. A large proportion of hotel IPOs are actually hotel management firms or REITs, such as LaSalle Hotel Properties, Hersha Hospitality, or Red Lion Hotels, all of which were also listed in mid 1998 to early 1999. While these firms are surely well-known, well-respected firms in hospitality, they are also likely to be less understood by the average investor in the early stages of the company's existence owing to the complexity of the firm's operations and business models.

\subsection{Demand Revelation and Share Allocation}

Ljungqvist and Wilhelm (2002) find that institutions that reveal more valuable information during the registration period are rewarded with higher allocations when such information is positive. Lin et al (2003) further point out that, by only doing so, can banks reward investors for telling the truth while simultaneously reducing the total underpricing of IPOs, hence maximizing proceeds to issuers. The intuition for this relationship again follows from the 5 rules outlined before. Since all investors receive the same offer price, the only way to reward investors who reveal higher levels of demand is to give them more shares. In this way, those who truthfully reveal that they are willing to pay a higher price receive more shares as a reward. If investors offer a low price in the hopes of generating a weaker book, the resulting offer price may be lower but others who bid higher and participants who buy the stock subsequent to the IPO will be

\footnotetext{
${ }^{4}$ The tech company in the example is a tech manufacturing firm not an internet firm. During this period, there was a stock-price bubble and high tech internet firms had extremely high first-day returns. These very high returns for internet firms are not typical for most other firms.
} 
the ones who benefit. As a result, the discretion given to investment banks to allocate more shares to those investors who signal higher levels of demand and to deals with a stronger book helps to ensure that all participants tell the truth. As pointed out in Ritter and Welch (2002), the share allocation decision is perhaps the most telling and promising indication of how banks use and reward investors in the bookbuilding and IPO process.

The pattern of percent change in shares offered shown in Table 6 is consistent with this intuition for the aggregate investor group studied here. The percent change in shares offered is defined as the final number of shares offered less the number of shares filed, divided by the number of shares files, and then multiplied by 100 . When the offer price is set above (below) the filing range, investors as a whole are rewarded with more (fewer) shares. In other words, when bookbuilding is strong, share allocation should be larger so as to reward investors involved in bookbuilding for revealing their strong demand. Indeed we find that the "Above" group receive a 5\% larger allocation whereas the "Below" group receives a $6 \%$ smaller one. ${ }^{5}$ As such, for strong deals, a higher offer price is struck but investors are rewarded with more shares. For weaker IPOs, investors receive smaller allocations of shares but the lower offer price still provides a positive first-day return for investors. The pair-wise difference in allocation between the "Above" and "Below" groups (11\%) is significantly positive. As before, the F-statistics show that the trend is monotonically increasing in the revealed demand. In other words, the higher the demand, the higher the offer price, the higher the allocation. Again the only exception is the Hotel industry, presumably due to the small sample size. Indeed, Table 6 shows

\footnotetext{
${ }^{5}$ Note that, based on supply/demand arguments alone, a larger allocation of shares would imply greater supply and hence a lower price and return. Hence, standard supply/demand arguments do not explain the positive relation between share allocation and return. We likewise find that the correlation between the percent change in shares offered and the first-day return is positive, indicating that IPOs may be oversubscribed.
} 
that issues above the filing range are twice as likely to increase in number of shares as issues that are within or below the filing range. Deals in the "Above" group increase share allocations $52 \%$ of the time while decreasing only $7 \%$. Likewise, issues below the filing range will decrease $50 \%$ of the time while only increasing $19 \%$. These findings are consistent with the rationale that investors receiver a higher (smaller) allocation and hence a higher gross profit (lower loss) when truthfully revealing strong (weak) demand.

\section{Conclusion}

This paper investigates the relationship between IPO underpricing and the bookbuilding process in the hospitality sector. Substantial IPO underpricing is documented in the hospitality as well as in the Restaurant and Hotel sub-sectors. This underpricing manifests itself as the return provided on the first day of trading subsequent to an IPO and serves to provide profit to investors who assisted the investment bank in the determination of the final offer price by truthfully revealing their demand. While this underpricing is often considered a cost to the original owners of the firm, both theoretical models and empirical evidence exist that suggests that underpricing acts as a necessity of the IPO process. Our study finds that underpricing is related to the information revelation process inherent in bookbuilding that occurs prior to the IPO period. We find evidence that investment banks purposefully offer investors a first-day return in order to induce them to engage in pre-IPO bidding for shares, a process that banks then use to determine the true demand for the IPO.

Specifically, investors are willing to truthfully reveal their demand, despite a resulting increase in the offer price, because investment banks will purposefully keep the 
offer price low enough and allocations large enough to generate a substantial first-day return for investors. For strong IPOs, investors reveal strong demand but are rewarded with large allocations of shares at an offer price that provides positive gross returns. For weak IPOs, investors likewise tell the truth but receive smaller allocations and very little underpricing. They are rewarded with a small return but, more importantly, will maintain a strong relationship with the issuing bank, guaranteeing them future participation in potentially better IPOs. Consistent with this conjecture, we find that underpricing levels are significantly positive in general and that underpricing levels and allocations increase in the level of demand revealed in the pre-IPO process. That is, the higher the demand, the higher the eventual offer price, the larger the gross first-day returns, and the larger the total allocation of shares. The study further finds that banks are generally unbiased in their determination of the filing range as the midpoint of the initial filing range is not significantly different from the eventual offer price. Specifically, we find that:

1. When truthful revelation of strong demand drives the offer price above the filing range, investors receive a 39\% first-day return and additional share allocations of $5.15 \%$

2. When truthful revelation of weak demand drives the offer price below the filing range, investors receive a $4.64 \%$ first-day return and reduced share allocations of $5.95 \%$.

When the IPO is weak (strong), a small (large) return is realized and small (large) number of shares are allocated. As such, investors are induced to truthfully reveal their demands, even if it eventually drives up the offer price, because they know they will be rewarded for doing so with higher returns and larger allocations. We believe these to be strong 
incentives for truth-telling.

This study seeks to add color and clarity to the larger discussion of IPOs. Equity offerings are clearly an important and popular form of financing. Especially in the cash intensive sector of hospitality, such sources of capital are many times critical to fund growth and expansion. Though entrepreneurs or private firm managers may at first prefer not to see any underpricing and would likewise prefer not to deliver a large fee/gross spread to the investment bank, it is often unavoidable. Investment banks offer the important service of bridging the information gap between managers and the capital market, and underpricing is a necessary part of the IPO process as it provides incentive for the capital market to reveal their demand for the issuing firm's stock. 


\section{References}

Akerlof, George, 1970, “The Market for 'Lemons': Quality Uncertainty and the Market Mechanism,” Quarterly Journal of Economics, August 1970, pp. 488-550.

Benveniste, Lawrence M. and Paul A. Spindt, 1989, "How Investment Bankers Determine the Offer Price and Allocation of Initial Public Offerings," Journal of Financial Economics, Vol. 24, pp. 343-362.

Benveniste, Lawrence M. and William J. Wilhelm, 1990, “A comparative analysis of IPO proceeds under alternative regulatory environments," Journal of Financial Economics, Vol. 28, pp. 173-207.

Bubna, Amit and Prabhala, Nagpurnanand R., 2007, "When Bookbuilding Meets IPOs", Indian School of Business and University of Maryland, Working Paper.

Canina, Linda, 1996, "Initial Public Offerings in the Hospitality Industry: Underpricing and Overperformance". Cornell Hotel and Restaurant Administration Quarterly, Vol. 37, No. 5, pp. 18-25.

Canina, L. and Gibson, S., 2003, "Understanding first-day returns of hospitality initial public offerings," Cornell Hotel and Restaurant Administrative Quarterly, 44 (August), 17-28.

Gu, Zheng, 1996, "Financial performances of new IPO gaming companies", The Bottom Line. Vol. 11, Iss. 1, pp. 10.

Hanley, Kathleen Weiss, 1993, "The Underpricing of Initial Public Offerings and the Partial Adjustment Phenomenon," Journal of Financial Economics, Vol. 34, pp. 231-250. 
Hanley, Kathleen Weiss and William J. Wilhelm, 1995, "Evidence on the Strategic Allocation of Initial Public Offerings," Journal of Financial Economics, Vol. 37, pp. 239-257.

Ibbotson, Roger G. and Jeffrey F. Jaffe, 1975, "Hot Issue Markets," The Journal of Finance, Vol. 30, No. 4, pp. 1027-1042.

Jenkinson, Tim, Alan D. Morrison, and William J. Wilhelm, 2003, "Why are European IPOs so Rarely Priced Outside the Indicative Price Range?", Oxford Financial Research Center Working Paper No. 2003-FE-05.

Krigman, Laurie, Wayne H. Shaw, and Kent L. Womack, 1999, "The Persistence of IPO Mispricing and the Predictive Power of Flipping," The Journal of Finance, Volume 54 Issue 3, pp. 1015 - 1044.

Lee, Inmoo, Scott Lockhead, and Jay Ritter, 1996, “The Costs of Raising Capital,” The Journal of Financial Research, Spring 1996, pp. 59-74.

Lin, Ji-Chai, Lee, Yi-Tsung and Liu, Yu-Jane, 2003, "Why Have Auctions Been Losing Market Shares to Bookbuilding in IPO Markets?", Louisiana State University and National Chengchi University, Working Paper.

Logue, Dennis Emhardt, 1972, “An Empirical Appraisal of the Efficiency of the Market for First Public Offerings of Common Stock," The Journal of Finance, Vol. 27, No. 1, p. 142

Loughran, Tim and Jay R. Ritter, 2002, "Why Has IPO Underpricing Changed over Time," University of Notre Dame and the University of Florida.

Ljungqvist, Alexander and William J. Wilhelm, 2002, "IPO Allocations: Discriminatory 
or Discretionary?" New York University and the University of Virginia.

Ritter, Jay R. \& Ivo Welch, 2002, “A Review of IPO Activity, Pricing, and Allocations," The Journal of Finance, Vol. 57, p. 1795.

Atkinson, S.M.; LeBruto, S.M, 1995, "Initial public offerings in the gaming industry: an empirical study", International Journal of Hospitality Management, Volume 14, Number 3, pp. 288-292(5).

Sherman, Ann E., 2000, "IPOs and Long Term Relationships: An Advantage of Book Building," The Review of Financial Studies, Vol. 13, pp. 697-714 , 2000.

Smith, Randall and Kate Kelly, 2003, "More Disclosure on Distribution of IPOs Looms," Wall Street Journal, May 12, 2003, pp. C1 and C9.

Smith, Richard L. and Kutsuna, Kenji, 2000, "How IPO Pricing Method Affects Underpricing and Issue Cost: Evidence on Japan's Change from Auction Method Pricing to Bookbuilding," Claremont University and Osaka City University, Working Paper.

Spatt, Chester and Sanjay Srivastava, 1991, "Preplay Communication, Participation Restrictions, and Efficiency in Initial Public Offerings," The Review of Financial Studies, Vol. 4, No. 4, pp. 709-726.

Stoll, Hans R. and Anthony J. Curley, 1970, "Small Business and the New Issues Market for Equities," The Journal of Financial and Quantitative Analysis, Vol. 5, No. 3, pp. 309-322.

Stangeland, David A. and Steven Zheng, 2007, "IPO underpricing, firm quality, and analyst forecasts," Financial Management, Vol. 36, Iss. 2. 
Table 1: Hospitality IPO Market

This table shows the the number of IPOs, and the average value of IPOs in thousands of dollars by year and over various periods for the hospitality sector as a whole and for the restaurant and hotel sectors separately. The offer value is the product of the offer price per share and the number of shares offered. The averages over the various periods are computed across the IPOs issued over that period. For example, the average offer value for the 1981-1989 period was computed as the average across all IPOs issued over the 1981-1989 period.

\begin{tabular}{|c|c|c|c|c|c|c|}
\hline \multirow[b]{2}{*}{ Year } & \multicolumn{2}{|r|}{ Hospitality } & \multicolumn{2}{|r|}{ Restaurants } & \multicolumn{2}{|r|}{ Hotels } \\
\hline & $\begin{array}{l}\text { Number } \\
\text { of IPOs }\end{array}$ & Average Offer Value & $\begin{array}{l}\text { Number } \\
\text { of IPOs }\end{array}$ & Average Offer Value & $\begin{array}{l}\text { Number } \\
\text { of IPOs }\end{array}$ & Average Offer Value \\
\hline & & $(\$ 000)$ & & $(\$ 000)$ & & $(\$ 000)$ \\
\hline 1981 & 4 & $\$ 8,984.00$ & 4 & $\$ 8,984.00$ & 0 & \\
\hline 1982 & 8 & $\$ 7,525.16$ & 8 & $\$ 7,525.16$ & 0 & \\
\hline 1983 & 15 & $\$ 9,747.51$ & 15 & $\$ 9,747.51$ & 0 & \\
\hline 1984 & 9 & $\$ 16,236.78$ & 7 & $\$ 13,079.07$ & 2 & $\$ 54,577.50$ \\
\hline 1985 & 4 & $\$ 9,057.81$ & 3 & $\$ 8,077.08$ & 1 & $\$ 12,000.00$ \\
\hline 1986 & 3 & $\$ 32,453.00$ & 2 & $\$ 36,679.50$ & 1 & $\$ 24,000.00$ \\
\hline 1987 & 4 & $\$ 44,562.62$ & 2 & $\$ 24,775.00$ & 2 & $\$ 128,700.46$ \\
\hline 1988 & 0 & & 0 & & 0 & \\
\hline 1989 & 1 & $\$ 26,175.00$ & 1 & $\$ 26,175.00$ & 0 & \\
\hline 1990 & 0 & & 0 & & 0 & \\
\hline 1991 & 5 & $\$ 28,430.00$ & 5 & $\$ 28,430.00$ & 0 & \\
\hline 1992 & 10 & $\$ 27,103.93$ & 8 & $\$ 26,527.41$ & 2 & $\$ 58,820.00$ \\
\hline 1993 & 11 & $\$ 34,282.71$ & 6 & $\$ 24,279.17$ & 5 & $\$ 231,434.82$ \\
\hline 1994 & 10 & $\$ 31,138.05$ & 6 & $\$ 19,114.58$ & 4 & $\$ 196,693.00$ \\
\hline 1995 & 6 & $\$ 48,716.67$ & 4 & $\$ 21,375.00$ & 2 & $\$ 206,800.00$ \\
\hline 1996 & 20 & $\$ 53,992.38$ & 11 & $\$ 21,146.36$ & 9 & $\$ 847,237.50$ \\
\hline 1997 & 6 & $\$ 27,231.25$ & 3 & $\$ 23,800.00$ & 3 & $\$ 91,987.50$ \\
\hline 1998 & 2 & $\$ 63,712.50$ & 1 & $\$ 49,800.00$ & 1 & $\$ 77,625.00$ \\
\hline 1999 & 2 & $\$ 34,992.53$ & 2 & $\$ 34,992.53$ & 0 & \\
\hline 2000 & 0 & & 0 & & 0 & \\
\hline 2001 & 3 & $\$ 73,463.59$ & 3 & $\$ 73,463.59$ & 0 & \\
\hline 1981-2001 & 123 & $\$ 30,744.00$ & 91 & $\$ 20,347.65$ & 32 & $\$ 60,308.62$ \\
\hline 1981-1989 & 48 & $\$ 15,135.35$ & 42 & $\$ 12,076.63$ & 6 & $\$ 36,546.33$ \\
\hline 1990-2001 & 75 & $\$ 40,733.54$ & 49 & $\$ 27,437.09$ & 26 & $\$ 65,792.22$ \\
\hline
\end{tabular}




\section{Table 2: Variables of Interest Related to the Determination of Whether the Filing Range is an Unbiased Assessment of the Offer Price}

This table presents the values of various variables of interest related to the determination of whether the initial filing offer range reported in the prospectus is an unbiased assessment of the final offer price in which shares are offered to regular investors. The values are reported for the hospitality industry as a whole as well as for two sub-samples: restaurants and hotels. For each of these three data samples, the results are presented across all IPOs (Column (1)) and for three sub-samples that were determined based upon the categorization of the relationship between the offer price and the filing range. The IPOs included in Column (2) represent those in which the offer price was set below the offer range; Column (3) represent those in which the offer price was set within the offer range; and Column (4) represent those in which the offer price was set above the offer range. The dollar width of the filing range was computed as the high price in the offer range minus the low price; the percent width of the offer range was computed as the dollar width divided by the low price multiplied by 100; the midpoint of the offer range is the average of the high and low prices of the offer range; the offer price revision was computed as the offer price less the midpoint of the filing range; and the percentage offer price revision was computed as the difference between the offer price and the midpoint of the filing range divided by the midpoint of the filing range multiplied by 100 .The means are computed by first computing the value of the variable for each IPO and then averaging these values across the IPOs in each sample. For example, for the mean percentage offer price revision, first the percentage difference was computed for each IPO and then the average was taken of these computed values across the IPOs. The numbers in parentheses are t-statistics. It also shows the number of IPOs in each sample and the percentage of the IPOs in each of the three groups categorized by the relationship between the final offer price and the filing range. t-statistics are in parentheses.

\begin{tabular}{|l|c|c|c|c|}
\hline \multicolumn{5}{|c|}{ Table 2 Panel A: Hospitality } \\
\hline & \multirow{2}{*}{ All } & \multicolumn{2}{|c|}{ IPOs Categorized According to: } \\
& Offer Price & Offer Price & Offer Price \\
& IPOs & Below Filing Range & Within Filing Range & Above Filing Range \\
\hline Mean & $(1)$ & $(2)$ & $(3)$ & $(4)$ \\
Dollar width of offer range & $\$ 1.93$ & $\$ 1.97$ & $\$ 1.90$ & $\$ 1.98$ \\
Percent width of offer range & $19.02 \%$ & $18.11 \%$ & $19.53 \%$ & $18.87 \%$ \\
Midpoint of offer range & $\$ 11.63$ & $\$ 12.52$ & $\$ 11.06$ & $\$ 11.94$ \\
Actual offer price & $\$ 11.52$ & $\$ 9.98$ & $\$ 10.96$ & $\$ 14.70$ \\
Offer price revision & $-\$ 0.11$ & $-\$ 2.55$ & $-\$ 0.11$ & $\$ 2.77$ \\
(t-statistic) & $(-0.58)$ & $(-12.35)$ & $(-1.10)$ & $(10.66)$ \\
Percentage offer price revision & $-1.07 \%$ & $-21.20 \%$ & $-1.49 \%$ & $23.80 \%$ \\
(t-statistic) & $(-0.65)$ & $(-12.04)$ & $(-1.63)$ & $(10.28)$ \\
\hline Number of IPOs & 123 & 32 & 64 & 27 \\
Percentage of IPOs & $100 \%$ & $26 \%$ & $52 \%$ & $22 \%$ \\
\hline
\end{tabular}




\begin{tabular}{|c|c|c|c|c|}
\hline \multicolumn{5}{|c|}{$\begin{array}{c}\text { Table } 2 \text { Continued: Variables of Interest Related to the Determination of Whether the Filing Range } \\
\text { is an Unbiased Assessment of the Offer Price }\end{array}$} \\
\hline \multicolumn{5}{|c|}{ Table 2 Panel B: Restaurants } \\
\hline & & \multicolumn{3}{|c|}{ IPOs Categorized According to: } \\
\hline & All & Offer Price & Offer Price & Offer Price \\
\hline & IPOs & Below Filing Range & Within Filing Range & Above Filing Range \\
\hline Mean & (1) & (2) & (3) & (4) \\
\hline Dollar width of offer range & $\$ 1.90$ & $\$ 1.96$ & $\$ 1.83$ & $\$ 1.98$ \\
\hline Percent width of offer range & $19.39 \%$ & $18.11 \%$ & $20.00 \%$ & $19.66 \%$ \\
\hline Midpoint of offer range & $\$ 11.09$ & $\$ 12.19$ & $\$ 10.31$ & $\$ 11.41$ \\
\hline Actual offer price & $\$ 10.93$ & $\$ 9.61$ & $\$ 10.24$ & $\$ 14.20$ \\
\hline Offer price revision & $-\$ 0.16$ & $-\$ 2.59$ & $-\$ 0.07$ & $\$ 2.79$ \\
\hline (t-statistic) & $(-0.70)$ & $(-11.15)$ & $(-0.61)$ & $(8.60)$ \\
\hline Percentage offer price revision & $-1.28 \%$ & $-21.73 \%$ & $-1.11 \%$ & $24.93 \%$ \\
\hline (t-statistic) & $(-0.64)$ & $(-11.78)$ & $(-0.97)$ & $(8.47)$ \\
\hline Number of IPOs & 91 & 26 & 45 & 20 \\
\hline Percentage of IPOs & $100 \%$ & $29 \%$ & $49 \%$ & $22 \%$ \\
\hline \multicolumn{5}{|c|}{ Table 2 Panel C: Hotels } \\
\hline & & \multicolumn{3}{|c|}{ IPOs Categorized According to: } \\
\hline & $\begin{array}{c}\text { All } \\
\text { IPOs }\end{array}$ & $\begin{array}{c}\text { Offer Price } \\
\text { Below Filing Range }\end{array}$ & $\begin{array}{c}\text { Offer Price } \\
\text { Within Filing Range }\end{array}$ & $\begin{array}{c}\text { Offer Price } \\
\text { Above Filing Range }\end{array}$ \\
\hline Mean & (1) & (2) & (3) & (4) \\
\hline Dollar width of offer range & $\$ 2.03$ & $\$ 2.00$ & $\$ 2.05$ & $\$ 2.00$ \\
\hline Percent width of offer range & $17.98 \%$ & $18.11 \%$ & $18.43 \%$ & $16.63 \%$ \\
\hline Midpoint of offer range & $\$ 13.18$ & $\$ 13.96$ & $\$ 12.84$ & $\$ 13.43$ \\
\hline Actual offer price & $\$ 13.21$ & $\$ 11.58$ & $\$ 12.64$ & $\$ 16.14$ \\
\hline Offer price revision & $\$ 0.03$ & $-\$ 2.38$ & $-\$ 0.20$ & $\$ 2.71$ \\
\hline (t-statistic) & $(0.09)$ & $(-4.93)$ & $(-1.02)$ & $(6.45)$ \\
\hline Percentage offer price revision & $-0.47 \%$ & $-18.88 \%$ & $-2.40 \%$ & $20.57 \%$ \\
\hline$(\mathrm{t}$-statistic) & $(-0.17)$ & $(-3.60)$ & $(-1.60)$ & $(6.93)$ \\
\hline Number of IPOs & 32 & 6 & 19 & 7 \\
\hline Percentage of IPOs & $100 \%$ & $19 \%$ & $59 \%$ & $22 \%$ \\
\hline
\end{tabular}




\section{Table 3: IPO Underpricing}

This table presents the IPO underpricing for the hospitality industry as a whole as well as for two subsamples: restaurants and hotels. For each of these three data samples, the results are presented across all IPOs,Column (1) and for three subsamples that were determined based upon the categorization of the relationship between the offer price and the filing range. The IPOs included in Column (2) represent those in which the offer price was set below the offer range; Column (3) represent those in which the offer price was set within the offer range; and Column (4) represent those in which the offer price was set above the offer range.

Underpricing is defined as the first day return, that is: $\mathrm{P}_{1} / \mathrm{P}_{\mathrm{o}}-1$ where $\mathrm{P}_{1}$ is the first-day closing price and $\mathrm{P}_{\mathrm{o}}$ is the offer price. A mean-difference test of Above-Below underpricing, Column (5) shows that the Above mean is significantly higher than the Below mean and, an F-test of equality, Column (6), confirms inequality of means across the three filing range groups.

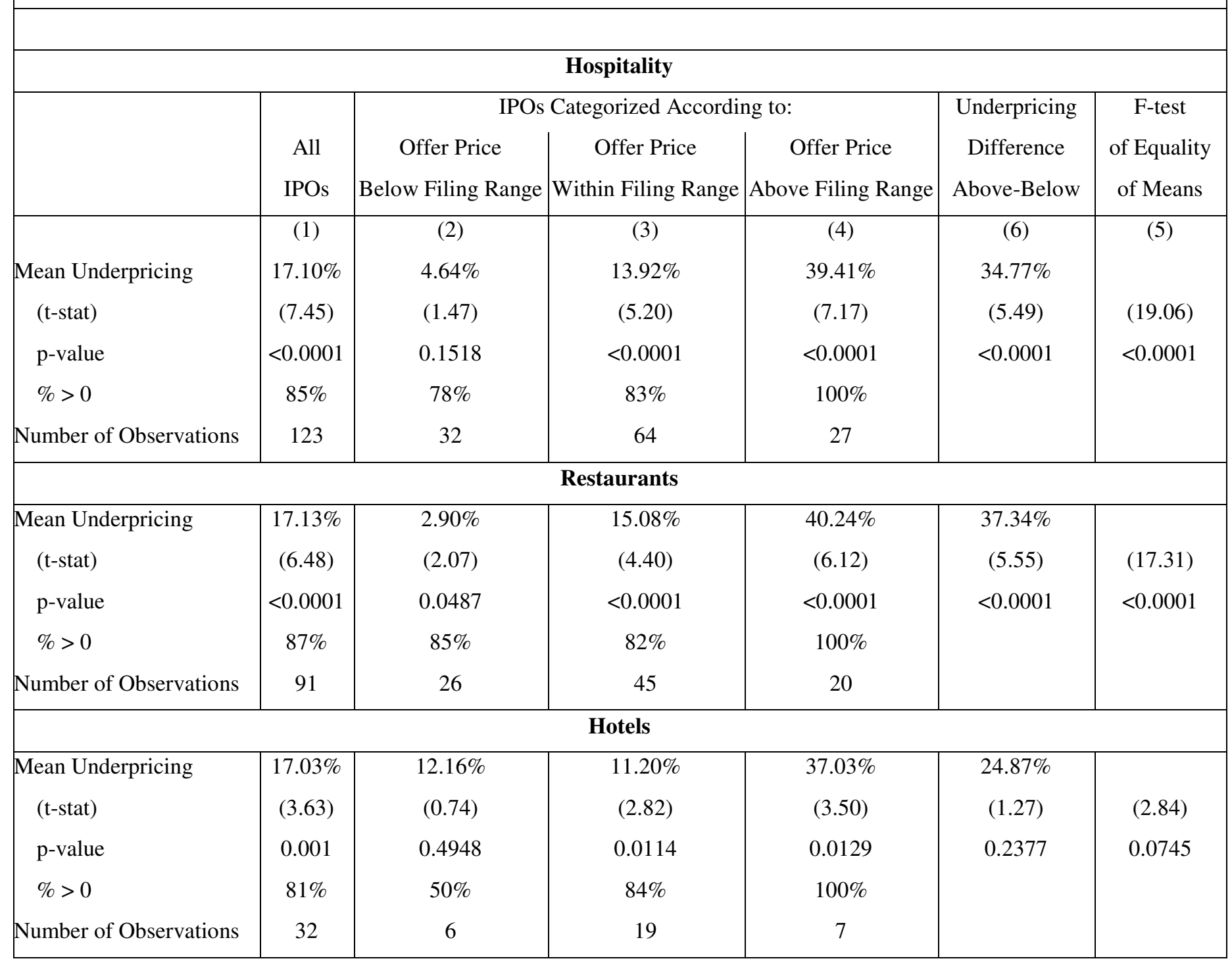




\section{Table 4: IPO Under-pricing}

This table presents IPO under-pricing for the overall market, the hospitality industry and the casino industry over various periods. Column (1) lists the reference for the studies of the overall market (Column(3))and of the casino industry (Column(5)). Column (2) shows the time period for which the average underpricing was computed in each of the referenced studies. Column (4) shows the average underpricing for the hopitality IPOs included in this study's data sample over the same period as for the overall market and the casino industry.

\begin{tabular}{|c|c|c|c|c|}
\hline \multirow[b]{2}{*}{ Reference } & \multirow[b]{2}{*}{ Period } & \multicolumn{3}{|c|}{ Mean Underpricing } \\
\hline & & $\begin{array}{l}\text { Overall } \\
\text { Market }\end{array}$ & Hospitality & Casino \\
\hline (1) & $(2)$ & (3) & (4) & $(5)$ \\
\hline Stangeland, David A. and Steven Zheng, 2007 & $1982-1998$ & $12.91 \%$ & $17.47 \%$ & \\
\hline Krigman, Laurie, Wayne H. Shaw, and Kent L. Womack, 1999 & $1988-1995$ & $12.30 \%$ & $26.97 \%$ & \\
\hline Loughran, Tim and Jay R. Ritter, 2002 & $1990-1998$ & $14.80 \%$ & $22.14 \%$ & \\
\hline Atkinson, S.M.; LeBruto, S.M, 1995 & 1992-1993 & & $36.77 \%$ & $30.63 \%$ \\
\hline
\end{tabular}




\section{Table 5: IPO Under-pricing}

This table presents the IPO under-pricing for the overall market and for hospitality industry as a whole over the 1983-1987 period. For each of these two data samples, the results are presented for three subsamples that were determined based upon the categorization of the relationship between the offer price and the filing range. The results presented in Column (1) are from the study by Hanley (1993). Column (2) present the results over the 1983-1987 period from the hospitality data sample used in this study. The IPOs included in the row entitled "Below Filing Range" represent those in which the offer price was set below the offer range; the IPOs included in the row entitled "Within Filing Range"represent those in which the offer price was set within the offer range; and the IPOs included in the row entitled "Above Filing Range" represent those in which the offer price was set above the offer range.

\begin{tabular}{|c|c|c|}
\hline \multirow{2}{*}{ Offer Price } & \multicolumn{2}{|c|}{ Mean Underpricing 1983-1987 } \\
\cline { 2 - 3 } & Hanley, Kathleen Weiss, 1993 & Hospitality \\
\hline & Overall Market & $(2)$ \\
Below Filing Range & $(1)$ & $0.32 \%$ \\
Within Filing Range & $0.60 \%$ & $11.89 \%$ \\
Above Filing Range & $10.00 \%$ & $30.26 \%$ \\
\hline
\end{tabular}




\section{Table 6: Share Allocation}

This table presents the percentage change in share allocation for the hospitality industry as a whole as well as for two subsamples: restaurants and hotels. For each of these three data samples, the results are presented across all IPOs, Column (1) and for three subsamples that were determined based upon the categorization of the relationship between the offer price and the filing range. The IPOs included in Column (2) represent those in which the offer price was set below the offer range; Column (3) represent those in which the offer price was set within the offer range; and Column (4) represent those in which the offer price was set above the offer range. The percentage change in share allocation is defined as the number of shares sold minus the number of shares filed divided by the number of shares filed multiplied by 100. A mean-difference test of Above-Below underpricing, Column (5), shows that the Above mean is significantly higher than the Below mean and, an F-test of equality, Column (6) confirms inequality of means, across the three filing range groups.

\section{Hospitality}

\begin{tabular}{|c|c|c|c|c|c|c|}
\hline & \multirow[b]{2}{*}{$\begin{array}{l}\text { All } \\
\text { IPOs }\end{array}$} & \multicolumn{3}{|c|}{ IPOs Categorized According to: } & \multirow{2}{*}{$\begin{array}{c}\% \text { Change in Shares } \\
\text { Difference } \\
\text { Above-Below }\end{array}$} & \multirow{2}{*}{\begin{tabular}{|c} 
F-test \\
of Equality \\
of Means
\end{tabular}} \\
\hline & & $\begin{array}{c}\text { Offer Price } \\
\text { Below Filing Range }\end{array}$ & \begin{tabular}{|c|} 
Offer Price \\
Within Filing Range
\end{tabular} & $\begin{array}{c}\text { Offer Price } \\
\text { Above Filing Range }\end{array}$ & & \\
\hline Mean \% Change in Shares & $1.20 \%$ & $-5.95 \%$ & $3.11 \%$ & $5.15 \%$ & $11.10 \%$ & \\
\hline (t-stat) & $(0.99)$ & $(2.14)$ & $(1.95)$ & $(3.09)$ & $(3.42)$ & $(6.91)$ \\
\hline $\mathrm{p}$-value & 0.3237 & 0.0407 & 0.0555 & 0.0047 & 0.0013 & 0.0014 \\
\hline$\%>0$ & $30 \%$ & $19 \%$ & $27 \%$ & $52 \%$ & & \\
\hline$\%<0$ & $18 \%$ & $50 \%$ & $6 \%$ & $7 \%$ & & \\
\hline$\%=0$ & $52 \%$ & $31 \%$ & $67 \%$ & $41 \%$ & & \\
\hline Number of Observations & 123 & 32 & 64 & 27 & & \\
\hline \multicolumn{7}{|c|}{ Restaurants } \\
\hline Mean \% Change in Shares & $1.65 \%$ & $-6.60 \%$ & $4.46 \%$ & $6.07 \%$ & $12.67 \%$ & \\
\hline (t-stat) & $(1.05)$ & $(2.01)$ & $(2.07)$ & $(2.99)$ & $(3.28)$ & $(6.22)$ \\
\hline $\mathrm{p}$-value & 0.2961 & 0.0554 & 0.0445 & 0.0076 & 0.0021 & 0.0030 \\
\hline$\%>0$ & $34 \%$ & $19 \%$ & $33 \%$ & $55 \%$ & & \\
\hline$\%<0$ & $19 \%$ & $50 \%$ & $7 \%$ & $5 \%$ & & \\
\hline$\%=0$ & $47 \%$ & $31 \%$ & $60 \%$ & $40 \%$ & & \\
\hline Number of Observations & 91 & 26 & 45 & 20 & & \\
\hline \multicolumn{7}{|c|}{ Hotels } \\
\hline Mean \% Change in Shares & $-0.08 \%$ & $-3.07 \%$ & $-0.09 \%$ & $2.52 \%$ & $5.59 \%$ & \\
\hline (t-stat) & $(0.06)$ & $(0.69)$ & $(0.06)$ & $(0.93)$ & $(1.07)$ & $(0.88)$ \\
\hline $\mathrm{p}$-value & 0.953 & 0.5224 & 0.9514 & 0.3901 & 0.3148 & 0.4254 \\
\hline$\%>0$ & $19 \%$ & $17 \%$ & $11 \%$ & $43 \%$ & & \\
\hline$\%<0$ & $16 \%$ & $50 \%$ & $5 \%$ & $14 \%$ & & \\
\hline$\%=0$ & $66 \%$ & $33 \%$ & $84 \%$ & $43 \%$ & & \\
\hline Number of Observations & 32 & 6 & 19 & 7 & & \\
\hline
\end{tabular}


